\section{AB0173 LONG NON-CODING RNA, LINC00487 EXPRESSION IS UPREGULATED IN B CELLS AND CORRELATES TO DISEASE ACTIVITY IN PATIENTS WITH PRIMARY SJÖGREN'S SYNDROME}

Jun Inamo ${ }^{1}$, Katsuya Suzuki ${ }^{1}$, Masaru Takeshita ${ }^{1}$, Yoshiaki Kasai ${ }^{2}$, Rina Kurisu ${ }^{2}$ Maiko Takiguchi ${ }^{2}$, Yuumi Okuzono ${ }^{2}$, Shinya Tasaki ${ }^{2}$, Tsutomu Takeuchi ${ }^{1}{ }^{1}$ Keio University School of Medicine, Tokyo, Japan; ${ }^{2}$ Takeda Pharmaceutical Company Limited, Tokyo, Japan

Background: Primary Sjögren's syndrome (pSS) is a systemic autoimmune disease characterized by interferon signature [1] and exocrine gland dysfunction which leads to dryness of the eyes and mouth [2]. B cells are considered to play an important role in the pathogenesis of pSS. Dysregulation of B cells can lead to production of anti-Sjögren's syndrome-related antigen A (anti-SSA) autoantibodies.

Objectives: We investigated the differential gene expression of peripheral $B$ cell subsets to reveal the precise role of B cells in the pathogenesis of pSS.

Methods: We enrolled pSS patients $(n=6)$ and healthy controls $(H C)(n=6)$, with matching for age and sex. Peripheral $B$ cells acquired from the participants were separated by cell sorting into 4 subsets: $C^{2} 38^{-} \lg D^{+}, C D^{2} 8^{+} \lg D^{+}, C D 38^{\text {high }} \operatorname{lgD}{ }^{+}$ and $\mathrm{CD} 8^{ \pm} \lg \mathrm{D}^{-}$. Total RNA was extracted and gene expression was measured using the Human Genome U133 Plus 2.0 Array (Affymetrix). The data were bioinformatically analyzed with reference to the corresponding clinical information.

Results: Using principal component and clustering analyses, we found that transcript expression patterns depended on cell type rather than clinical condition (pSS or $\mathrm{HC}$ ). Interferon signaling was the most upregulated pathway in many of $B$ cell subsets of pSS patients. As well as HLA and interferon signature genes, LINC00487 was upregulated significantly in all B cell subsets. Its fold changes in $\mathrm{CD}^{-} \lg \mathrm{D}^{+}, \mathrm{CD} 8^{+} \operatorname{lgD} \mathrm{D}^{+}, \mathrm{CD} 38^{\text {high }} \lg \mathrm{D}^{+}$and $\mathrm{CD}^{\circ} 8^{ \pm} \lg \mathrm{D}^{-}$were $8.4(\mathrm{p}=0.038), 11.3$ $(p=0.014), 8.5(p=0.089)$ and $6.37(p=0.078)$, respectively. In addition, the normalized intensity value of LINC 00487 was significantly correlated with disease activity score in all pSS B cell subsets, namely $C D 38^{-} \lg \mathrm{D}^{+}$(Figure $A, r=0.96, p=0.002$ ), $\mathrm{CD}^{\circ} 8^{+} \operatorname{lgD}{ }^{+}$(Figure $\left.\mathrm{B}, \mathrm{r}=0.90, \mathrm{p}=0.015\right), \mathrm{CD} 38^{\text {high }} \mathrm{IgD}^{+}$(Figure $\mathrm{C}, \mathrm{r}=0.81, \mathrm{p}=0.049$ ) and $\mathrm{CD}^{2} 8^{ \pm} \operatorname{lgD} \mathrm{D}^{-}$(Figure $\mathrm{D}, \mathrm{r}=0.96, \mathrm{p}=0.003$ ). The expression of LINC00487 in $\mathrm{B}$ cell lines was regulated by IFN $\alpha$.

Conclusion: Compared to $\mathrm{HC}$, patients with pSS showed upregulation of the interferon signaling pathway and LINC00487 gene in all B cell subsets. This upregulation correlated with disease activity and regulated by IFNa in B cell lines. These results may suggest that long non-coding RNA contributes to $B$ cell dysregulation in patients with pSS and the precise role of LINC00487 in B cell and pathogenesis of $\mathrm{pSS}$ requires further study.

\section{REFERENCES}

[1] Muskardin TLW, et al. Nat Rev Rheumatol 2018;14:214-228.

[2] Qin, B. et al. Ann Rheum Dis. 2015;74:1983-1989.

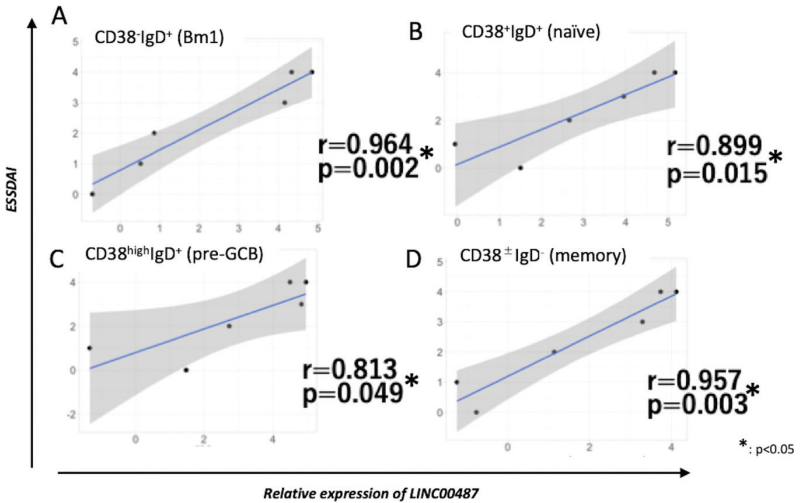

Figure. Correlation between the expression of LINC00487 and disease activity score in each B cell subset.

ESSDAI; EULAR Sjögren's Syndrome Disease Activity Index

Disclosure of Interests: Jun Inamo: None declared, Katsuya Suzuki: None declared, Masaru Takeshita Grant/research support from: Novartis, Yoshiaki Kasai Employee of: Takeda Pharmaceutical Company Limited, Rina Kurisu Employee of: Takeda Pharmaceutical Company Limited, Maiko Takiguchi Employee of: Takeda Pharmaceutical Company Limited, Yuumi Okuzono Employee of: Takeda Pharmaceutical Company Limited, Shinya Tasaki Employee of: Takeda Pharmaceutical Company Limited, Tsutomu Takeuchi Grant/research support from: Astellas Pharma Inc, Chugai Pharmaceutical Co, Ltd., Daiichi Sankyo Co., Ltd., Takeda Pharmaceutical Co., Ltd., AbbVie GK, Asahikasei Pharma Corp., Mitsubishi Tanabe Pharma Co., Pfizer Japan Inc., Eisai Co., Ltd., AYUMI Pharmaceutical Corporation, Nipponkayaku Co. Ltd., Novartis
Pharma K.K., Grant/research support from: AbbVie, Asahi Kasei, Astellas, AstraZeneca, AYUMI, Bristol-Myers Squibb, Chugai, Daiichi Sankyo, Eisai, Eli Lilly Japan, Janssen, Mitsubishi Tanabe, Nippon Kayaku, Novartis, Pfizer Japan Inc Taiho, Taisho Toyama, Takeda, Teijin, Grant/research support from: Astellas Pharma Inc., Bristol Myers Squibb, Chugai Pharmaceutical Co., Ltd., Mitsubish Tanabe Pharma Co., Pfizer Japan Inc., Santen Pharmaceutical Co., Ltd., Takeda Pharmaceutical Co., Ltd., Teijin Pharma Ltd., AbbVie GK, Asahi Kasei Pharma Corp., Taisho Toyama Pharmaceutical Co., Ltd., SymBio Pharmaceuticals Ltd. Janssen Pharmaceutical K.K., Celltrion Inc., Nipponkayaku Co. Ltd., and UCB Japan, Consultant for: Astra Zeneca K.K., Eli Lilly Japan K.K., Novartis Pharma K. K., Mitsubishi Tanabe Pharma Co., Abbivie GK, Nipponkayaku Co.Ltd, Janssen Pharmaceutical K.K., Astellas Pharma Inc., Taiho Pharmaceutical Co. Ltd., Chugai Pharmaceutical Co. Ltd., Taisho Toyama Pharmaceutical Co. Ltd., GlaxoS mithKline K.K., UCB Japan Co. Ltd., Consultant for: AbbVie, Asahi Kasei, Astellas, AstraZeneca, AYUMI, Bristol-Myers Squibb, Chugai, Daiichi Sankyo, Eisai, Eli Lilly Japan, Janssen, Mitsubishi Tanabe, Nippon Kayaku, Novartis, Pfizer Japan Inc, Taiho, Taisho Toyama, Takeda, Teijin, Consultant for: Astra Zeneca K.K., Eli Lilly Japan K.K., Novartis Pharma K.K., Mitsubishi Tanabe Pharma Co., Asahi Kasei Medical K.K., AbbVie GK, Daiichi Sankyo Co., Ltd., Bristol Myers Squibb, and Nipponkayaku Co. Ltd., Speakers bureau: Astellas Pharma Inc., Bristol Myers Squibb, Chugai Pharmaceutical Co., Ltd., Mitsubishi Tanabe Pharma Co., Pfizer Japan Inc., Santen Pharmaceutical Co., Ltd., Takeda Pharmaceutical Co., Ltd., Teijin Pharma Ltd., AbbVie GK, Asahi Kasei Pharma Corp. Taisho Toyama Pharmaceutical Co., Ltd., SymBio Pharmaceuticals Ltd., Janssen Pharmaceutical K.K., Celltrion Inc., Nipponkayaku Co. Ltd., and UCB Japan, Speakers bureau: AbbVie, Asahi Kasei, Astellas, AstraZeneca, AYUMI, BristolMyers Squibb, Chugai, Daiichi Sankyo, Eisai, Eli Lilly Japan, Janssen, Mitsubishi Tanabe, Nippon Kayaku, Novartis, Pfizer Japan Inc, Taiho, Taisho Toyama Takeda, Teijin, Speakers bureau: AbbVie GK., Bristol-Myers K.K., Chugai Pharmaceutical Co. Ltd., Mitsubishi Tanabe Pharma Co., Pfizer Japan Inc., Astellas Pharma Inc, Diaichi Sankyo Co. Ltd., Eisai Co. Ltd., Sanofi K.K., Teijin Pharma Ltd., Takeda Pharmaceutical Co. Ltd., Novartis Pharma K.K.

DOI: 10.1136/annrheumdis-2019-eular.3939

\section{AB0174 CLINICAL SIGNIFICANCE OF THE URINARY CD11C+ MYELOID CELLS IN THE PATIENTS WITH LUPUS NEPHRITIS}

Jihye Kim ${ }^{1,2}$, Jae Hyung Jung ${ }^{1,2}$, Jung Sun Lee ${ }^{1}$, Ji Seon $\mathrm{Oh}^{1}$, Wook Jang Seo ${ }^{3}$, Yong-Gil Kim ${ }^{1}$, Chang-Keun Lee ${ }^{1}$, Bin Yoo ${ }^{1}$, Seokchan Hong ${ }^{1} .{ }^{1}$ University of Ulsan College of Medicine, Asan Medical Center, Seoul, Korea, Rep. of (South Korea);

${ }^{2}$ Asan Institute for Life Science, Seoul, Korea, Rep. of (South Korea); ${ }^{3}$ Veterans Health Service Medical Center, Seoul, Korea, Rep. of (South Korea)

Background: It is known that various immune cell populations play important pathogenic roles in lupus nephritis (LN). Kidney-infiltrating myeloid cells are responsible for the pathology in murine model for LN. However, the characteristics of myeloid cells in patients with LN have not previously been investigated because of difficulties of access to affected tissue. Recent studies have reported that the urine has become an alternative substitute for kidney tissue to study renal pathology.

Objectives: Therefore, we investigated the characteristics and functions of urinary myeloid cells in patients with LN.

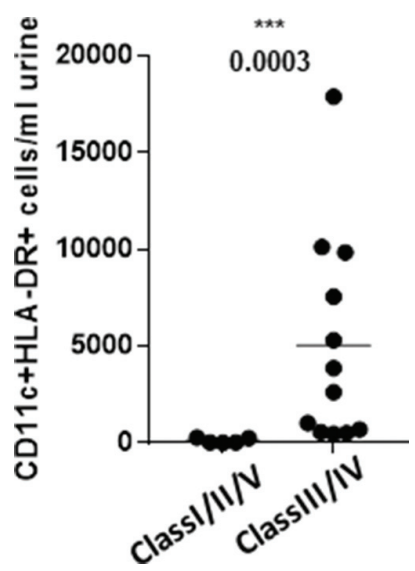

Methods: Within viable CD45+ cells, the frequency and absolute numbers of myeloid cells in the urine were examined after exclusion of lymphoid cells by expression of CD3, CD19 and CD56. Expression of phenotypic markers and 